\title{
THE DEFENSE OF "PASSING ON" IN TREBLE DAMAGE SUITS UNDER THE ANTITRUST LAWS*
}

IN private antitrust actions to recoup excessive prices charged by the defendant, the requirement that plaintiff have been "injured in his business or property" 1 may be rendered nugatory if recovery is granted where plaintiff has "passed on" the overcharges to customers. Section 4 of the Clayton Act permits any person injured "by reason of anything forbidden in the antitrust laws" to bring a civil action for "threefold the damages by him sustained."2 The preponderance of private antitrust litigation is brought subsequent to a successful government action against the defendant, ${ }^{3}$ since the judgment or decree obtained by the government, admissible as prima facie evidence of the requisite antitrust violation, ${ }^{4}$ eliminates the usually prohibitive burden of proving the violation independently..$^{5}$ The crucial issues in a treble damage action, therefore, are usually reduced to establishing that the prior violation has caused an injury to the plaintiff and proving the amount of damages sustained as a

*The Hanover Shoe, Inc. v. United Shoe Mach. Corp., Trade Reg. Rep. (1960 Trade Cas.) \ 69614 (M.D. Pa., Feb. 12, 1960), aff'd per curiam, TRADE REG. REP. (1960 Trade Cas.) \ 69754 (3d Cir., June 30, 1960), cert. denied, 29 U.S.I. WeEK 3154 (Nov. 15, 1960).

1. Any person who shall be injured in his business or property by reason of anything forbidden in the antitrust laws may sue therefor in any district court of the United States in the district in which the defendant resides or is found or has an agent, without respect to the amount in controversy, and shall recover threefold the damages by him sustained, and the cost of the suit, including a reasonable attorney's fee.

Clayton Act § 4, 38 Stat. 731 (1914), 15 U.S.C. § 15 (1958). This section supersedes Sherman Act $\S 7,26$ Stat. 210 (1890), which was repealed by the Act of July 7, 1955, 69 Stat. 283.

2. Clayton Act $\S 4,38$ Stat. 731 (1914), 15 U.S.C. $\S 15$ (1958).

3. See Bicks, The Department of Justice and Private Treble Damage Actions, 4 ANTITRUST BuLI. 1, 6-7 (1959); Comment, 61 Yale L.J. 1010, 1060 (1952).

4. Clayton Act § 5, 38 Stat. 731 (1914), as amended, 15 U.S.C. § 16 (1958). Section 5 does not apply, however, to "consent judgments or decrees entered before any testimony has been taken" or to a judgment or decree in a civil action brought by the government under 15 U.S.C. \& 15a (1958). Prior consent decrees "may nonetheless come in through the back door of judicial notice." Bicks, supra note 3 , at 7 . Section 5 additionally tolls the statute of limitations as to any private right of action during the pendency of government litigation and for one year thereafter.

Without this provision, prior judgments would have no evidentiary value to private litigants. See Buckeye Powder Co. v. E. I. DuPont de Nemours Powder Co., 248 U.S. 55, 63 (1918). For a discussion of the damaging potential of section 5 on a defendant's case, see Seely, The Pitfalls Which Lurk in Government Litigation for Defendants Who May be Subjected to Treble Damage Actions, 4 AnTITrust Buld. 17 (1959). For a discussion of the practical limitations of section 4, see Comment, 61 YALE L.J. 1010, 1040-41 (1952).

5. See McAllister, The Big Case: Procedutral Problems in Antitrust Litigation, 64 HaRv. L. Rev. 27 (1950). See generally AtT'y Gen. Nat'l Comm. Antitrust Rep. 349 (1955). 
result of the injury. ${ }^{6}$ Where the action involves illegal overcharges exacted by the defendant, and plaintiff is a "middleman"-one who either resells the item or uses it in the manufacture of another product-the defendant may attempt to prove that plaintiff has recouped the total overcharge by raising the price to his customers, and has, consequently, not been injured. ${ }^{7}$ Alternatively, the defendant may argue that damages should be reduced to the extent that plaintiff's customers have absorbed the overcharge. ${ }^{8}$ This "passing on" defense has been recognized as valid in several contexts.

In the Oil Jobber cases, decided by the Seventh and Eighth Circuits in the 1940's, plaintiffs subjected to overcharges were unable to demonstrate that they had sustained damages. ${ }^{9}$ The defendant in each case was a member of a group which had been convicted of conspiracy to raise the spot-market price of gasoline in the Midwest. ${ }^{10}$ Plaintiffs were jobber-distributors who purchased gasoline from members of the conspiracy and resold it to service stations. Their resale price was set by the defendants, according to a formula which added a fixed profit margin to whatever price plaintiffs had been charged for the gasoline. ${ }^{11}$ The jobbers sought to recover threefold the amount of the overcharge. Recovery was uniformly denied. The naked overcharge was insufficient to support a finding of damages because plaintiffs had passed on the overcharge to their customers under the fixed-margin formula. ${ }^{12}$ One court

6. See Seely, supra note 4, at 18; Loevinger, The LAw of Free Enterprise 264 (1949).

7. See Wolfe v. National Lead Co., 225 F.2d 427, 429, 433-34 (9th Cir.), cert. denied, 350 U.S. 915 (1955) (affirming decree dismissing action); Clark Oil Co. v. Phillips Petroleum Co., 148 F.2d 580, 582 (Sth Cir.), ccrt. denied, 326 U.S. 734 (1945) (affirming summary judgment for defendants); Leonard v. Socony-Vacuum Oil Co.; 42 F. Supp. 369, 370-71 (W.D. Wis.), appeal dismissed, 130 F.2d 535 (7th Cir. 1942) (granting defendants' motion for partial summary judgment).

8. See Northwestern Oil Co. v. Socony-Vacuum Oil Co., 138 F.2d 967, 969 (7th Cir. 1943), cert. denied, 321 U.S. 792 (1944); Twin Ports. Oil Co. v. Pure Oil Co., 119 F.2d 747 (8th Cir.), cert. denied, 314 U.S. 644 (1941) ; Banana Distribs. v. United Fruit Co., 162 F. Supp. 32, 47 (S.D.N.Y..1958) ; cf. Farrey's, Inc. v. Supplee-Biddle Hardware Co., 103 F. Supp. 488, 490-91 (E.D. Pa. 1952).

9. Clark Oil Co. v. Phillips Petroleum Co., 148 F.2d 580 (8th Cir.), cert. denied, 326 U.S. 734 (1945) ; Leonard v. Socony-Vacuum Oil Co., 42.F. Supp. 369 (W.D. Wis.), appeal dismissed, 130 F.2d 535 (7th Cir. 1942); Northwestern Oil Co. v. Socony-Vacuum Oil Co., 138 F.2d 967 (7th Cir. 1943), cert. denied, 321 U.S. 792 (1944); Twin Ports Oil Co. v. Pure Oil Co., 119 F.2d 747 (8th Cir.), cert. denied, 314 U.S. 644 (1941).

10. United States v. Socony-Vacuum Oil Co., 310 U.S. 150.(1940).

11. See, e.g., Twin Ports Oil Co. v. Pure Oil.Co., 119 F.2d 747 (8th Cir. 1941). In fact, the"formula-was computed with the retail-price as the starting point. Ibid.-

12. Clark Oil Co. v. Phillips Petroleum Ca., 148 F.2d 580, 582 (8th Cir.); $\ddot{c} c r t . ~ d e n i c d$, 326 U.S. 734 (1945) ; Northwestern Oil Co. v. Socony-Vacuum Oil Co., 138 F.2d 967, 971 (7th Cir. 1943), cert. denied, 321 U.S. 792 (1944) ("plaintiff has wholly failed to prove any loss . . but rather . . . the increased cost ... was passed on to the ultimate consumer") ; Twin Ports Oil Co. v. Pure Oil Co., 119 F.2d 747, 750 (Sth Cir.), cert. dented, 314 U.S. 744 (1941); Leonard v. Socony-Vacuum Oil Co., 42. F. Supp. 369, 371 (W.D. Wis.), appeal dismissed, 130 F.2d 535 (7th Cir. 1942) ("if the increase in price to plaintiff 
said, "Plaintiffs are seeking not compensation for damages suffered by defendants' illegal acts, but profits because of said acts."13

The Ninth Circuit, in a direct holding, ${ }^{14}$ and the Fourth Circuit in dictum, ${ }^{15}$ have cited the Oil Jobber cases with approval in sustaining the "passing on" defense. In the Ninth Circuit case, plaintiff alleged that defendant had restricted the supply of ingredients necessary to plaintiff's paint manufacturing business, and that damage had been sustained because plaintiff had been forced to purchase a more expensive substitute. Plaintiffs' profits during the years of the alleged antitrust violation, however, had been greater than those made in the free market which followed; the court, therefore, required proof that the increased cost had been absorbed by plaintiff and not passed on to its customers. ${ }^{10}$ Failing this, plaintiff was denied recovery. The "passing on" issue was not decisive in the Fourth Circuit decision because plaintiffs had failed to show a violation of the antitrust laws. Yet the court stated in dictum that "any increases in the price of defendant's product were passed on ... to the ultimate consumer; and under the settled decisions, plaintiff has suffered no injury for which the law will permit him treble damages."17

Proof that the plaintiff has actually sustained damages has been held irrelevant in one analogous class of cases-those brought under the Interstate Commerce Act to enforce an ICC reparation order compelling the carrier to refund freight charges in excess of Commission-established rates. ${ }^{18} \mathrm{~A}$ carrier may not avoid the reparation order by showing that the plaintiff-shipper succeeded in passing on the excess freight charge to others. ${ }^{19}$ The ICC reparation order, however, serves a regulatory rather than a compensatory function. It is designed to maintain uniformity among the rates set by the ICC. Courts, recognizing that the reparation order does not always compensate the party ultimately damaged, ${ }^{20}$ have awarded relief on the premise that carriers ought not be allowed to retain more than the Commission-established rates provide. ${ }^{21}$ Multiple recoveries against the carrier are avoided by the rule that the action to recover an overcharge may be brought only by the party who paid

was passed on by him to his customers, he has suffered no pecuniary loss or injury to his business or property").

13. Clark Oil Co. v. Phillips Petroleum Co., supra note 12, at 582.

14. Wolfe v. National Lead Co., 225 F.2d 427 (9th Cir.), cert. denied, 350 U.S. 915 (1955).

15. Miller Motors, Inc. v. Ford Motor Co., 252 F.2d 441, 448 (4th Cir. 1958).

16. Wolfe v. National Lead Co., 225 F.2d 427, 432 (9th Cir.), cert. denied, 350 U.S. 915 (1955).

17. Miller Motors, Inc. v. Ford Motor Co., 252 F.2d 441, 448 (4th Cir. 1958).

18. See 24 Stat. 382 (1887), as amended, 49 U.S.C. \$\$ 8-9 (1958).

19. See, e.g., Southern Pac. Co. v. Darnell-Taenzer Lumber Co., 245 U.S. 531 (1918); cf. Louisville \& N.R.R. v. Sloss-Sheffield Iron \& Steel Co., 269 U.S. 217, 235-36 (1925) (Brandeis, J.) ; Adams v. Mills, 286 U.S. 397, 406-07 (1932) (Brandeis, J.).

20. See Adams v. Mills, 286 U.S. 397, 407-08 (1932) ; Southern Pac. Co. v. DarnellTaenzer Lumber Co., 245 U.S. 531, 534 (1918).

21. See Southern Pac. Co. v. Darnell-Taenzer Lumber Co., supra note 20; Burgess v. Transcontinental Freight Bureau, 13 I.C.C. 668, 680 (1908), 
the excess charges. ${ }^{22}$ Although recovery may be a windfall to the shipper, the difficulty of searching out the persons (probably consumers) who ultimately bear the overcharge makes it impossible to divest the carrier of the overcharge by any other means. ${ }^{23}$ The distinctive nature of the reparation order becomes apparent when it is compared to the shipper's action against a common carrier for giving illegal rebates to other shippers. ${ }^{24}$ In this kind of case, the Supreme Court has reasoned that to measure damages simply by the amount of the rebates "would create a legalized, but endless, chain of departures from the tariff ... [and] would destroy the equality and certainty of rates ...."2s The shipper must prove actual monetary loss in order to recover. ${ }^{26}$

Hanover Shoe, Inc. v. United Shoe Mach. Corp ${ }^{27}$ is the first case to reject the "passing on" defense in a private antitrust suit. United Shoe Machinery Corporation had been convicted of violating the Sherman Act in 1953. ${ }^{28}$ Hanover Shoe, Inc., brought a treble damage action, based upon that judgment, for injury alleged to have resulted from excessive rental and royalty charges for shoe machinery. A separate trial was held to determine whether Hanover had been "injured" within the meaning of section $4 .{ }^{29}$ It was assumed for purposes of the separate trial that the violation of law and the overcharge each existed as alleged. Hanover claimed that it suffered injury at the moment of overcharge; defendant contended that plaintiff had not been injured because all excess costs had been passed on to plaintiff's customers.

The payment of the overcharge was held by the district court to constitute the requisite "actual harm" to plaintiff, and passing on was ruled "invalid" as a defense. In the court's view, "the plaintiff's injury occurred when it was charged too much for the machinery," because, absent the overcharge, there would have been more money in the corporate treasury available for dividends or expansion..$^{30}$ Relying on general tort doctrine, the court explained that subsequent developments which "let an injured plaintiff escape some of the ultimate consequences of the wrong done him do not inure to the benefit of the

22. Baker Mfg. Co. v. Chicago \& N.W. Ry., 21 I.C.C. 605,607 (1911) ; Nicola, Stone \& Myers Co. v. Louisville \& N.R.R., 14 I.C.C. 199, 207-09 (1908). If consignee, as agent for consignor, physically pays the freight, consignor retains right to reparation. Louisville \& N.R.R. v. Sloss-Sheffield Iron \& Steel Co., 269 U.S. 217, 238 (1925).

23. See, e.g., Burgess v. Transcontinental Freight Bureau, supra note 21, at 680 .

24. See 24 Stat. 382 (1887), as amended, 49 U.S.C. $\$ 8$ (1958).

25. Pennsylvania R.R. v. International Coal Mining Co., 230 U.S. 184, 206 (1913).

26. See Davis v. Portland Seed Co., 264 U.S. 403, 415, 417, 425 (1924); ICC v. United States ex rel. Campbell, 289 U.S. 385, 390 (1933).

27. Trade Reg. Rep. (1960 Trade Cas.) I 69614 (M.D. Pa., Feb. 12, 1960), aff'd per curiam, TRAde REg. Rep. (1960 Trade Cas.) \ 69754 (3d Cir., June 30, 1960), cert. denied, 29 U.S.L. WEER 3154 (Nov. 15, 1960). The district court opinion is hereinafter cited as "Hanover opinion."

28. United States v. United Shoe Mach. Corp., 110 F. Supp. 295 (D. Mass. 1953), aff'd per curiam, 347 U.S. 521 (1954).

29. Hanover opinion at 76475 ; see FED. R. CIv. P. $42(\mathrm{~b})$.

30. Hanover opinion at 76476 . 
defendant."31 The district court's conclusion also rested on Southern Pac. Co. v. Darnell-Taenzer Lumber Co.,32 an ICC rate reparation case in which the Supreme Court held that damages are measured at the moment of overcharge, without regard to subsequent developments. The court distinguished the Oil Jobber cases by creating what may become known as the "original package" doctrine of the antitrust laws: the plaintiffs in the Oil Jobber cases, were middlemen reselling "a product supplied for resale by a Sherman Act violator whereas plaintiff here is simply a lessee of equipment which sells its own product." 33 The lessee of equipment, the court reasoned, was therefore a "consumer." This distinction seems to restrict the district court's earlier statement that events subsequent to the overcharge are irrelevant to the question of injury; such events may be relevant if the plaintiff fits the court's idea of a "middleman."

An interlocutory appeal was permitted, since the question was one which involved "a controlling question of law as to which there is substantial ground for difference of opinion."34 The Court of Appeals for the Third Circuit affirmed in a per curiam opinion which found the district court's opinion "thoroughly convincing" in its rejection of the defense. ${ }^{35}$ Defendant's claim that allowance of a recovery would result in a windfall to plaintiff was rejected as inconsistent with the overriding congressional policy to impose treble damages as a penalty to deter monopolistic practices.

The district court's conclusion would have been supported by general tort doctrine if the court, in finding that plaintiff had been "injured," had meant to distinguish between "injury" as the violation of a statutory right sufficient to support a claim for relief, and "injury" as the damage caused by that violation. Common law tort doctrine recognizes this distinction. ${ }^{36}$ It considers injuria sine damno to be actionable, because the law presumes that damages flow from the violation of a right. ${ }^{37}$ Applying this distinction in the Hanover case, the district court might have limited its holding to the conclusion that the overcharge was actionable as a violation of plaintiff's rights, postponing until

31. Ibid.

32. 245 U.S. 531 (1918).

33. Hanover opinion at 76477-78. The district court distinguished the Ninth Circuit case, Wolfe v. National Lead Co., 225 F.2d 427 (9th Cir.), cert. denied, 350 U.S. 915 (1955), as dictum because ". . . there was no showing that the manufacturer paid any more for the raw material than he would have in a competitive market ...." Hanover opinion at 76478 n.12. This is not accurate; the Wolfe opinion, supra at 432, finds an overcharge: "[L]ithopone ... cost considerably more; and it appears that ... plaintiffs paid $\$ 18,400$ more for it . . . than they would have spent for a comparable quantity of titanium pigment."

34. Hanover opinion at 76478 .

35. Hanover Shoe, Inc. v. United Shoe Mach. Corp., Trade Reg. Rep. (1960 Trade Cas.) If 69754 (3d Cir., June 30, 1960).

36. See Cooley, Torts 74 (2d ed. 1888) ; Hale, Damages 16 (1896).

37. See Webb v. Portland Mfg. Co., 29 Fed. Cas. 506 (No. 17322) (C.C.D. Me. 1838) (Story, J.) ; Wipple v. Cumberland Mfg. Co., 29 Fed. Cas. 934 (No. 17516) (C.C.D. Me. 1843). 
trial the question whether plaintiff actually had been damaged by the overcharge. The common law distinction between "injury" and "damage," however, is not applicable to the treble damage action. Section 4 allows a private party to sue if he has been "injured in his business or property," and courts have construed this provision to require that plaintiff offer evidence of pecuniary loss as a prerequisite to maintaining the action. ${ }^{38}$ The district court itself seemed to recognize this requirement; its decision to uphold the complaint is based on a finding that plaintiff had suffered recoverable damages. Principal reliance was placed on language in the Darnell-Taenzer case indicating that the law does not go beyond the instant of overcharge in computing damages. ${ }^{39}$ Also, the court clearly states that the plaintiff is entitled to "recover" the excessive charges, regardless of passing on. ${ }^{40}$ Thus, while the court did not actually compute the damages in this action, its holding is dispositive on the damage question to the extent that consideration of "passing on" is precluded in the calculation of damages. The ultimate incidence of the overcharge will be irrelevant.

The court's extension of common law tort doctrine to support a finding of actual damages is inaccurate. Although injuria sine damno is actionable, the amount of recovery will be nominal absent proof of actual pecuniary loss. ${ }^{41}$ The Darnell-Taenzer case, cited in support of the district court's damage theory, was an action to enforce an ICC reparation order and not an action for treble damages under the antitrust laws. The Supreme Court recognized this distinction in Keogh v. Chicago \& N.W. Ry. ${ }^{42}$ There, a conspiracy in restraint of trade had raised freight rates on plaintiff's product. Plaintiff filed a complaint with the ICC, which approved the allegedly unreasonable rates after holding extensive hearings. Having no grounds upon which to seek a reparation order, plaintiff brought an action for treble damages under the antitrust laws. The Court denied recovery on the ground that plaintiff had failed to prove that the unreasonably high rates had resulted in actual loss to him. Justice Brandeis distinguished the action from one for enforcement of a reparation order:

38. See, e.g., Keogh v. Chicago \& N.W. Ry., 260 U.S. 156, 164-65 (1922) (quoted infra at note 43). In antitrust cases the statute of limitations begins to run when damages occur. Bluefields S.S. Co. v. United Fruit Co., 243 Fed. 1, 20 (3d Cir. 1917). See also cases cited notes $7 \& 8$ supra.

39. Hanover opinion at 76477 .

40. Id. at 76478 .

41. See, e.g., Little v. Stanback, 63 N.C. 285, 287 (1869); Bagby v. Harris, 9 Ala. 173,177 (1846). The early case of Chattanooga Foundry \& Pipe Works v. City of Atlanta, 203 U.S. 390 (1906), cited by the Hanover court, Hanover opinion at 76477, does not compel alteration of this principle. That case contains language which might be read as limiting the inquiry in a treble damage action to the moment of overcharge. See 203 U.S. at 399. The Court, however, never faced that issue; it was concerned only with which of three state statutes of limitations was applicable. See id. at 397. The Court's refusal to go beyond the "first step" therefore goes only to the focal point for determining the nature of the cause of action.

42. 260 U.S. 156 (1922). 
[U]nder $\S 7$ of the antitrust act, as under $\S 8$ of the Act to Regulate Commerce ... recovery cannot be had unless it be shown, that . . . damages in some amount susceptible of expression in figures resulted. These damages must be proved by facts from which their existence is logically and legally inferable .... It is not like those cases where a shipper recovers from the carrier the amount by which its exaction exceeded the legal rate. Southern Pacific Co. v. Darnell-Taenzer Co. ${ }^{43}$

Whatever the force of Darnell-Taenzer as authority for measuring damages at the instant of overcharge, the Supreme Court has clearly limited its application to ICC reparation order cases, and has explicitly rejected it as authority in a treble damage action.

The district court's statement that events after the moment of overcharge are irrelevant to the damages issue fails to discriminate between general principles of damage computation in cases of personal injury and those applicable to recovery for pecuniary harm. ${ }^{44}$ The authorities cited by the court ${ }^{45}$ do not support its conclusions in the latter context. The Restatement of Torts is directly contradictory:

In determining the measure of recovery, aside from harm to body, emotions or reputation, a balance sheet is in effect set up by the court in which are stated the items of assets and liabilities which have been affected by the tort (a) before the tort and (b) as they appear at the time of trial. . . . The difference to the extent that it results from the tort constitutes the theoretical measure of recovery. ... . Tortfeasor is liable only for the amount of the net harm which he has caused. . . .46

Those sections of McCormick, Damages, cited by the court merely state the author's preference, under admittedly conflicting authority, for, (1) the rule which denies the tortfeasor the benefit of gratuitous payments made to the plaintiff by third parties or under an indemnity contract, and (2) the rule that an injured employee may recover the value of lost wages even though his employer gratuitously continues his wage payments. ${ }^{47}$ These rules seem inapplicable to the situation before the court; Hanover bears no relation to an action to recover lost wages, nor is it reasonable to categorize the higher payments made by Hanover's customers, which enabled it to pass on the overcharge, as "gratuitous" or made under an indemnity contract. If $\mathrm{McC}$ ormick is applicable at all, the higher customer payments would seem to fall within his gen-

43. Id. at 164-65.

44. Sce LoEvinger, op. cit. supra note 6 , at 264.

45. Hanover opinion at $76477 \mathrm{n} .5$ (citing MCCoRMrick, Damages $\S 90$, at 324 (1935) and Restatement, Torts $\S 920$, comment $e$ (1939)), n.6 (citing MCCoRMtCK, sipra and Restatement, supra at $\$ 924$, comment $f$ ), n.7 (citing MCCoRMICK, supra, $\S 87$, at 310 and RestateMent, supra at $\$ 920$, comment $e$ ).

46. Restatearent, Torts $\$ 905$, comment a (1939) ; accord, Merchant Shippers Ass'n v. Kellogg Express \& Draying Co., 28 Cal. 2d 594, 170 P.2d 923 (1946) ; Douglas v. Prescott, $31 \mathrm{Ga}$. App. 684, 121 S.E. 689 (1924) ; Enterprise Garnetting Co. v. Forcier, 69 R.I. 455, 35 A.2d 1 (1943).

47. McCoranick, Daneages $\$ \S 87,90 \& n .12$ (1935). 
eral category of benefits which reduce damages because they have been made possible by defendant's conduct ; 48 the increases in the price of shoes was possible only because United Shoe had monopolized the entire shoe machinery industry and had thus established equally excessive costs for all competing producers. Moreover, the Hanover court itself failed to adhere to its "instantof-overcharge" theory. Looking to the net effect on plaintiff's "total wealth," the court said:

If ... [plaintiff] had not thus been illegally charged for machinery it would have had more money to pay out in dividends, or to engage in a further development campaign to sell its shoes, or to raise the wages of its employees, or to enlarge its bank account as protection against a rainy day, or for all these things. ${ }^{49}$

In looking to the ultimate effect on Hanover's financial position, the court was properly applying general damage doctrine. But it was unjustified in offering this conclusion as a reason for rejecting the validity of the passing-on defense; plaintiff's supply of working capital would not have been impaired unless plaintiff had actually absorbed the excess cost. ${ }^{50}$

Finally, the court was satisfied that Hanover's position as lessee sufficiently distinguished it from the "middlemen" in the Oil Jobber cases. Perhaps this distinction was prompted by evidentiary considerations. "Passing on" is no doubt easier to visualize and to prove when the overcharge is attached to an identifiable item which is itself resold at a correspondingly higher price. But the distinction has no economic significance. Both the middleman and the lessee-manufacturer are charged excessive prices. Both recover the overcharge by raising the price of the commodity they sell. ${ }^{51}$ It is thus irrelevant whether the plaintiff resells the excessive-cost-item or uses it to manufacture a different product. In practical effect, Hanover is directly inconsistent with, and indistinguishable from, the Oil Jobber cases.

The inadequacies of the district court's opinion, however, do not compel the conclusion that passing on ought to be permitted as a defense. As the Third Circuit's per curiam affirmance implies, recognition of that defense might detract from the deterrent effect of treble damage actions. ${ }^{52}$ Authorities suggest

48. Id. at $\S 40$.

49. Hanover opinion at 76476 .

50. The court might, of course, have meant to refer to Hanover's financial position immediately after the overcharge. But in that case it would have had to assume, unreasonably, that decisions as to dividends and expansion are made instantaneously without consideration of a firm's financial position over a period of time.

51. The defense presumably would be ineffective where plaintiff's increased resale prices were attributable to an increase in the cost of other factors. Cf. Twin Ports Oil Co. v. Pure Oil Co., 119 F.2d 747, 750-51 (8th Cir. 1941) ; Northwestern Oil Co. v. SoconyVacuum Oil Co., 138 F.2d 967, 969-70 (7th Cir. 1943) ; Clark Oil Co. v. Phillips Petroleum Co., 148 F.2d 580, 582 (8th Cir. 1945).

52. Trade Reg. Rep. (1960 Trade Cas.) If 69754 (3d Cir., June 30, 1960). Commentators disagree as to section 4's deterrent effect. Compare, Comment, 61 YALE L.J. 1010, 1058-62 (1952), with Hamilton \& Tils, AntrTrust in Action 84-85 (TNEC monograph No. 16, 1941). 
that the treble damage remedy serves several functions. ${ }^{63}$ Certainly, it seeks to compensate injured plaintiffs. But, while section 4 is not technically a penal provision, ${ }^{\text {G- }}$ it may be the only effective sanction invoked against an antitrust violator. ${ }^{55}$ Where millions of dollars in overcharges are involved, a price fixer may treat the Sherman Act's $\$ 50,000$ criminal penalty ${ }^{50}$ as simply a cost of doing business. He may hesitate, however, when faced with a potential threefold liability. ${ }^{57}$ It may be necessary in some cases to forego accurate compensation of injured parties if this deterrent function is to be fully realized. Individual consumers or dealers who sustain the overcharge are unlikely to sue. Therefore, unless the first purchaser is allowed to recover what may to him be a windfall, the violator may escape liability altogether.

On the other hand, what little legislative history is available suggests that the private damage action was originally intended to provide a remedy to the party ultimately damaged. ${ }^{68}$ In fact, criticism of this remedy in the floor debates centered on the unlikelihood that the consumer- "the party necessarily damnified or injured"- - would ever be in a position to bring suit. ${ }^{59}$

53. See, e.g., United States v. National City Lines, Inc, 334 U.S. 573, 581 (1948) (section 4 provides broad, effective relief for injured parties); Quemos Theatre Co. v. Warner Bros. Pictures, 35 F. Supp. 949, 950 (D.N.J. 1940) ("an ancillary force of private investigators to supplement the Department of Justice in law enforcement") ; accord, Weinberg v. Sinclair Ref. Co., 48 F. Supp. 203, 205 (E.D.N.Y. 1942) ; Maltz v. Sax, 134 F.2d 2, 4 (7th Cir. 1943). See generally Bicks, supra note 3; HamrLton \& TirL, supra note 52, at 82; AtT'y Gen. Nat'i Conin. AntrTRust Rep. 378-80 (1955).

54. See Atlanta v. Chattanooga Foundry \& Pipeworks, 127 Fed. 23, 29 (6th Cir. 1903), aff'd, 203 U.S. 390 (1906) ; Hicks v. Bekins Moving \& Storage Co., 87 F.2d 583, 585 (9th Cir. 1937); United Copper Secs. Corp. v. Amalgamated Copper Co., 232 Fed. 574, 577 (2d Cir. 1916). Contra, Haskell v. Perkins, 28 F.2d 222 (D.N.J. 1928), rev'd on other grounds, 31 F.2d 53 (3d Cir. 1929). See generally Vold, Are Threefold Damages Under the Anti-Trust Act Penal or Compensatory?, 28 Ky. L.J. 117 (1939).

55. See Comment, 18 U. CHI. L. Rev. 130, 138 (1950).

56. 69 Stat. 282 (1955), 15 U.S.C. $\S 1,2$ (1958).

57. See Loevinger, op. cit. supra note 6, at 254; Comment, 34 VA. L. REv. 901,902 (1948). The awards have often exceeded one million dollars. Cooper, Treble DamagesReward for Private Enforcement of Federal Anti-Trust Lawes, 32 DICTA 293, 304 (1955).

58. See, 21 Cong. REC. 1767 (1890) (remarks of Senator George on the private remedy proposed in section 7 of Senator Sherman's original bill); id. at 2615 (remarks of Senator Coke).

59. See, id. at 3146 (remarks of Senator Regan); id. at 3150 (remarks of Senator George). When debating the private civil remedy of Senator Sherman's original bill, Senator George stated:

The right of action against the persons in the combination is given to the party damnified. Who is this party injured, when, as prescribed in the bill, there has been an advance in the price by the combination? ... The consumer is the party "damnified or injured."

This is the express provision of the bill, as I think is clear from the last clause of the first section. But even if it were not the express language of the bill, it so results as a logical necessity. An advance in price to the middlemen is not mentioned in the bill for the obvious reason that no such advance would damnify them; it would rather be a.benefit, as it would increase the value of the goods he has on hand. $\mathrm{He}$ 
Admittedly, limitation of the treble damage remedy to plaintiffs who bear the ultimate loss results in a haphazard disparity of sanctions: If the violator directly injures widely dispersed, unidentifiable consumers he faces only criminal penalties; but if he injures a consumer or absorbing middleman who has sustained sufficient damage to warrant litigation, the violator faces both private and governmental sanctions. Adoption of the Hanover rule, however, would only compound the random nature of the sanction. More violators would be assessed treble damages under Hanover, but some would still escape with only the criminal penalty. Treble damage liability would then depend on whether or not the violator operated through a middleman, or, to be exact, through a "middleman" middleman as opposed to a "consumer" middleman ${ }^{60}$ This is scarcely a more rational criterion, even in terms of deterrence; it is simply more inclusive. Thus the only policy served by the result in Hanover is that of increasing the deterrent effect of present antitrust law. But if the level of deterrence absent Hanover is felt to be inadequate, a statutory increase in criminal sanctions would meet this need more positively, uniformly and equitably than would the granting of an occasional windfall to a middleman. Moreover, since the antitrust violations immune from treble damage liability are those involving economic injury to broad unorganized segments of the public, criminal sanctions seem a more appropriate way of protecting and vindicating the interests injured.

Two additional reasons support this conclusion. The existence of the "passing on" defense will probably have little impact on the overall deterrent effect of treble damage liability. It is doubtful that an intentional violator will base his business decisions on the likelihood that customers will pass on the illegal exactions and that he can prove it at trial. ${ }^{61}$ Even if passing on is anticipated, the entire overcharge may not be passed on. Moreover, the resulting increase in the customer's price may result in other damage in the form of reduced volume and profits, for which the violator must respond threefold. ${ }^{62}$

The second reason lies in the unreasonable burden that rejection of the defense might impose on defendants. Not only would plaintiffs obtain money to which they were not entitled, but defendants might be forced to sustain liability in a succession of suits. Unlike the ICC reparation order doctrine, which

buys to sell again. He buys only for profits on a subsequent sale. So whatever he pays he receives when he sells, together with a profit on his investment; and so of all of them, including the last, who sells directly to the consumer. The consumer, therefore, paying all its increased price advanced by the middlemen and profits on the same, is the party necessarily damnified or injured.

$I d$. at 1767.

60. See text accompanying note 33 supra.

61. Of course, the prospect of treble damages would have no impact on the inadvertent violator. See Atr'y Gen. NAT'z Comm. Antrtrust Rep. 378-79 (1955); Bicks, supra note 3, at 13. See generally Kaysen \& Turner, Arms of Antitrust Policy 246-47, 257, 271-72 (1959).

62. See, e.g., Groves, Financing Government 110-11, 113-14, 121 (4th ed. 1954); Leftwich, The Price System and Resource Allocation 152-53 (1955). 
limits recovery to the party in privity with the carrier, treble damage recovery is not so limited. ${ }^{83}$ Therefore, if plaintift in Hanover had sold to a wholesaler who could prove absorbtion of the overcharge, the wholesaler would also have a cause of action against United Shoe. Indeed, there is nothing in the Hanover opinion to preclude recovery by as many consumers or consumer middlemen as the chain of distribution may contain, so long as each can prove an increase in costs due to the original overcharge. ${ }^{64}$ If the overcharge has injured the first purchaser despite its subsequent passing on, it will be equally injurious to the second and the third purchasers. ${ }^{65}$ Each has a separate injury for which the violator will be liable. In this case the liability of the initial seller would be far in excess of anything contemplated by section $4 .{ }^{66}$

63. Chattanooga Foundry \& Pipe Works v. Atlanta, 203 U.S. 390, 396-97 (1906); Clark Oil Co. v. Phillips Petroleum Co., 148 F.2d 580, 582-83 (8th Cir. 1945); Northwestern Oil Co. v. Socony-Vacuum Oil Co., 138 F.2d 967, 971 (7th Cir. 1943).

64. The violator would not be protected from additional suits by the doctrine of res judicata. Persons not party nor privy are not bound by the prior determination. RestateMIENT, JUdGMIENTS \& 93 (1942). See generally Developments in the Law-Res Judicata, 65 HARv. L. REv. 818, 855-65 (1952). The fact that other purchasers received their injury through the medium of the initial plaintiff would not render them privy to the original judgment. A privy is one whose rights to property occur after the institution of the suit which affects those rights. The doctrine does not apply to rights acquired before the adjudication. Bigelow v. Old Dominion Copper Co., 225 U.S. 111, 128-31 (1912) ; National Lead Co. v. Nulsen, 131 F.2d 51, 56 (8th Cir. 1942), cert. denied, 318 U.S. 758 (1943); Wise v. United States, 38 F. Supp. 130, 133 (W.D. Ky. 1941) ; California Bridge \& Constr. Co. v. United States, $50 \mathrm{Ct}$. Cl. 40, 57-60 (1915).

65. Increased use of class actions by injured antitrust plaintiffs makes the threat of suits by consumers and small retailers more apparent. See Kainz v. Anheuser-Busch, Inc., 194 F.2d 737 (7th Cir. 1952); Comment, 61 YaLE L.J. 1010, 1036-37 (1952); Comment, 34 VA. L. REv. 901, 924-25 (1948).

66. Upholding the validity of "passing on" as a defense will not entirely eliminate the possibility that a violator will be assessed more in damages than his conduct has actually caused. A passing-on situation raises the likelihood of successive actions by subsequent purchasers. If the share of overcharge absorbed by each plaintiff is determined in a separate action, the sum of the parts may be greater than the whole. Also, the cumulative litigation expenses and harassment involved in defending a series of such suits may be a vexatious burden in themselves. But in all probability, the prospect of duplicated damages and litigation expenses will not move a defendant to try to join all the causes in a single action because to do so would be to stir up remote plaintiffs who may never sue at all.

Nevertheless, defendants might be able to interplead all potential adverse claimants when they so desire. Rule 22 of the Federal Rules of Civil Procedure would allow this form of interpleader, but, since the reach of the district court's process under this rule is restricted to the territorial limits of the state in which it sits, FED. R. CIV. P. 82; 3 MoorE, Federal Practice If 22.04[2], at 3009-10 (1st ed. 1948), this interpleader would be of limited value. The jurisdictional limitations of Rule 22 might be avoided by using the statutory interpleader provided for in 28 U.S.C. $\$ 1335$ (1958), which reads in pertinent part:

(a) The district courts shall have original jurisdiction of any civil action of interpleader ... if (1) two or more adverse claimants of diverse citizenship . . . are claiming or may claim to be entitled to ... [the amount in question] ... and if 
(2) the plaintiff has deposited such ... [amount] or has paid the amount ... into the registry of the court or has given ... [the requisite] bond.

(b) Such an action may be entertained although the titles or claims of the conflicting claimants do not have a common origin, or are not identical, but are adverse to and independent of one another.

The diversity requirement might be met under the rule of Haynes v. Felder, 239 F.2d 686 (5th Cir. 1957), which finds diversity if any two of the adverse claimants are of diverse citizenship. Service of process under $\$ 1335$ is nationwide. 28 U.S.C. $\$ 2361$ (1958). Strictly interpreted, a bill of interpleader is only available when the moving party is totally disinterested in the fund in question. Where the claims are disputed, a bill in the nature of interpleader has been permitted when the plaintiff has asserted some other equitable reason for jurisdiction. 3 MOORE, op. cit. supra, $\llbracket 22.03$, at 3005-06, $\{22.07[1]$, at 3019-20. The deposit requirement of $\S 1335$, however, makes this procedure of dubious advantage, for seldom will defendants be willing to put up, or able to secure a bond for, the colossal sums sued for in treble damage actions. 